\title{
Kerosene tolerance in Achromobacter and Pseudomonas species
}

\author{
Mihaela Marilena Stancu(D
}

\begin{abstract}
Purpose: The aim of the present study was to investigate the tolerance of five new Achromobacter and Pseudomonas strains to kerosene and to establish if the production of several secondary metabolites increases or not when these bacteria were grown in the presence of kerosene. The biodegradation of kerosene by isolated bacteria was also investigated in this study.

Methods: Five Proteobacteria were isolated from different samples polluted with petroleum and petroleum products. Based on their morphological, biochemical, and molecular characteristics, isolated bacteria were identified as Achromobacter spanius IBB $\mathrm{BP}_{018}$ and $\mathrm{IBB}_{\mathrm{P}_{21} 1}$, Pseudomonas putida IBB $\mathrm{BB}_{\mathrm{P} 191}$ and Pseudomonas aeruginosa $\mathrm{IBB}_{\mathrm{P}_{20} 0}$ and $\mathrm{IBB}_{\mathrm{PO} 22}$.

Results: All these bacteria were able to tolerate and degrade kerosene. Higher tolerance to kerosene and degradation rates were observed for $P$. aeruginosa $\mathrm{IBB}_{\mathrm{Po} 20}$ and $I \mathrm{BB}_{\mathrm{P}_{022} \text {, }}$ compared with that observed for $A$. spanius $\mathrm{IBB}_{\mathrm{Po} 18}$ and $\mathrm{IBB}_{\mathrm{Po} 21}$, and P. putida IBB $\mathrm{BP}_{\mathrm{P} 19}$. All these bacteria were able to produce several secondary metabolites, such as surfactants and pigments. Glycolipid surfactants produced by $P$. aeruginosa IBB Po20 $_{\text {and }}$ aBB Po22 $_{\text {, }}$ A. spanius $\mathrm{IBB}_{\mathrm{P} 018}$ and $\mathrm{IBB}_{\mathrm{PO} 21}$, and $P$. putida $\mathrm{IBB}_{\mathrm{P} 019}$ have a very good emulsification activity, and their activity increased when they were grown in the presence of kerosene. The production of rhamnolipid surfactants by P. aeruginosa IBB poz20 $_{2}$ and $\mathrm{IBB}_{\mathrm{P} 022}$ was confirmed by detection of $r / A B$ gene involved in their biosynthesis. Pyocyanin and pyoverdin pigments were produced only by P. aeruginosa $\mathrm{IBB}_{\mathrm{Po} 20}$ and $\mathrm{IBB}_{\mathrm{Po} 22}$, while carotenoid pigments were produced by all the isolated bacteria. Significant changes in pigments production were observed when $P$. aeruginosa $\mathrm{IBB}_{\text {Po20 }}$ and

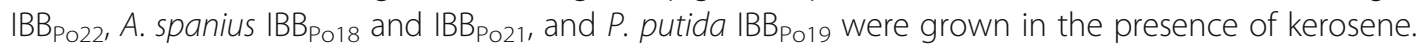

Conclusion: Due to their ability to tolerate and degrade kerosene, and also to produce several secondary metabolites, the isolated bacteria could be used in the bioremediation of kerosene-polluted environments.

Keywords: Achromobacter, Pseudomonas, Kerosene, Tolerance, Secondary metabolites

\section{Introduction}

The Achromobacter and Pseudomonas are two of the most diverse and ubiquitous Gram-negative bacterial genera whose species (sp.) were isolated worldwide from all types of environments, including from water, sediments, soil, and sludge (Leahy and Colwell 1990; Chikere et al. 2011; Mnif et al. 2011; Varjani 2017). Bacterial sp. of genera Achromobacter and Pseudomonas have considerable technological importance and include a variety of metabolically versatile bacteria with ability to utilize a wide range of simple and complex toxic organic compounds as

Correspondence: mihaela.stancu@ibiol.ro

Institute of Biology Bucharest of Romanian Academy, 296 Splaiul

Independentei, P.O. Box 56-53, 060031 Bucharest, Romania the carbon and energy sources (Chikere et al. 2011; Varjani 2017). These Gram-negative bacteria produce large amount of secondary metabolites, such as surfactants (Abdel-Mawgoud et al. 2009; Rocha et al. 2011; Rikalović et al. 2015; Joy et al. 2017) and pigments (Malik et al. 2012; El-Fouly et al. 2015) which are essential for their survival and enable some species to tolerate and degrade organic compounds that enters into the environment during petroleum extraction, transportation, storage, and processing activities (Leahy and Colwell 1990; Rocha et al. 2011). Generally, aliphatic and aromatic hydrocarbons which exist in the composition of petroleum and petroleum products are very toxic for most of the bacteria. Nevertheless, a number of bacteria able to tolerate and

(c) The Author(s). 2020 Open Access This article is distributed under the terms of the Creative Commons Attribution 4.0 International License (http://creativecommons.org/licenses/by/4.0/), which permits unrestricted use, distribution, and 
degrade different hydrocarbons have been reported (Leahy and Colwell 1990; Chikere et al. 2011; Mnif et al. 2011; Varjani 2017; Xu et al. 2018; Shahzadi et al. 2019). Most of the bacteria able to tolerate and degrade toxic hydrocarbons were isolated mainly from the petroleum and petroleum product-polluted sites. The indigenous bacteria which were exposed to aliphatic and aromatic hydrocarbons become adapted, exhibiting induction and repression of specific enzymes, genetic modifications which result in new metabolic capabilities, and selective enrichment of bacteria able to tolerate and degrade the hydrocarbons (Leahy and Colwell 1990; Chikere et al. 2011; Matilla 2018). Consequently, the isolation from the contaminated environments of bacteria with high hydrocarbon degrading ability can serve as promising tool for the bioremediation of petroleum and petroleum product-polluted sites (Patowary et al. 2016). Kerosene, also known as paraffin or paraffin oil, is a refined petroleum product which contains up to 260 aliphatic and aromatic hydrocarbons $\left(\mathrm{C}_{6}-\mathrm{C}_{17}\right)$, including toxic compounds, such as benzene, toluene, trimethylbenzene, ethylbenzene, xylenes, $n$-hexane, trimethylpentane, naphthalenes, and other PAHs (Ritchie et al. 2003; Shahzadi et al. 2019). Many isolated bacteria possess the ability to completely degrade only simple petroleum hydrocarbons. It is generally recognized that no single species is able to completely degrade any complex mixture of hydrocarbons (Chikere et al. 2011; Patowary et al. 2016). However, several Achromobacter and Pseudomonas strains able to grow on kerosene as the carbon and energy source have been reported (Silva et al. 2006; Ahamed et al. 2010; Mazumdar et al. 2015).

The aim of the present study was to investigate the tolerance of five new Achromobacter and Pseudomonas strains to kerosene and to establish if the production of several secondary metabolites (i.e., surfactants, pigments) increase or not when these bacteria were cultivated in liquid medium overlaid with kerosene. The presence of rhlAB (rhamnosyl transferase) gene was investigated for the isolated bacteria grown under the same conditions. The biodegradation of kerosene by Achromobacter and Pseudomonas isolates was also investigated in this study.

\section{Materials and methods}

\section{Isolation and characterization of Achromobacter and} Pseudomonas strains

Bacteria used in this study were isolated from different water, soil, and oily sludge samples polluted with petroleum and petroleum products (Poeni, Teleorman County, Romania), through enrichment cultures method as previously described (Stancu and Grifoll 2011). Enrichment cultures were speeded on nutrient-rich LB agar (Sambrook and Russel 2001), and growing colonies were further purified by repeated streaking. The isolates were maintained routinely by subculture in liquid LB medium containing $20 \mu \mathrm{g} \mathrm{ml}^{-1}$ ampicillin or kanamycin, incubated for 2 days at $30{ }^{\circ} \mathrm{C}$, and stored frozen at $-80{ }^{\circ} \mathrm{C}$ in $25 \%$ (v/v) glycerol.

Morphological (i.e., Gram reaction, shape, motility, pigments production, respiratory type) (Holt et al. 1994), biochemical (i.e., catalase, oxidase, lactose utilization, API 20 NE assay, bioMérieux, Marcy-l'Etoile, France), and molecular characteristics (i.e., DNA fingerprints, $16 \mathrm{~S}$ rRNA gene sequencing) of the bacterial isolates were further determined. Genomic DNA was extracted from these bacteria using the Pure Link genomic kit (Invitrogen, Carlsbad, CA, USA).

Polymerase chain reaction (PCR) amplification of $16 \mathrm{~S}$ rRNA gene was performed in a total reaction volume of $50 \mu \mathrm{l}$ using GoTaq G2 Flexi DNA polymerase (Promega, Madison, WI, USA) in the supplied buffer. The universal bacterial primers used were 27f and 1492r (Marchesi et al. 1998). Amplifications were carried out in a Mastercycler pro $\mathrm{S}$ (Eppendorf, Hamburg, Germany) using the following program: initial denaturation at $94{ }^{\circ} \mathrm{C}$ for 10 min, followed by 35 cycles of $94{ }^{\circ} \mathrm{C}$ for $1 \mathrm{~min}, 55^{\circ} \mathrm{C}$ for $30 \mathrm{~s}$, and $72{ }^{\circ} \mathrm{C}$ for $2 \mathrm{~min}$, with final extension at $72{ }^{\circ} \mathrm{C}$ for $10 \mathrm{~min}$. Restriction analyses of the amplified $16 \mathrm{~S}$ rDNA (ARDRA) were performed with EcoRI, HaeIII, and HhaI (Promega) in a total volume of $20 \mu \mathrm{l}$ at $37{ }^{\circ} \mathrm{C}$ for $3 \mathrm{~h}$. Reaction products and restriction fragments resolved by $2 \%(\mathrm{w} / \mathrm{v})$ agarose gel electrophoresis (Sambrook and Russel 2001) and stained with SYBR safe DNA gel stain (Invitrogen, Carlsbad, CA, USA) were visualized under ultraviolet (UV) light.

Random amplification of polymorphic DNA (RAPD) fragments was performed in a total reaction volume of $25 \mu \mathrm{l}$ using GoTaq G2 Flexi DNA polymerase (Promega) in the supplied buffer. The primers used were AP12 (Michaud et al. 2004) and AP5 (Pini et al. 2007). Amplifications were carried out in a Mastercycler pro $\mathrm{S}$ (Eppendorf) using the following program: initial denaturation at $94{ }^{\circ} \mathrm{C}$ for $10 \mathrm{~min}$, followed by 45 cycles of $94{ }^{\circ} \mathrm{C}$ for $1 \mathrm{~min}, 36{ }^{\circ} \mathrm{C}$ for $1 \mathrm{~min}$, and $72{ }^{\circ} \mathrm{C}$ for $2 \mathrm{~min}$, with final extension at $72{ }^{\circ} \mathrm{C}$ for $10 \mathrm{~min}$. Reaction products were visualized by $2 \%(\mathrm{w} / \mathrm{v})$ agarose gel electrophoresis (Sambrook and Russel 2001).

Sequencing of the amplified 16S rRNA gene was performed by the CeMIA (SA Larissa, Greece) using the amplification primers (27f and $1492 \mathrm{r}$ ). The new sequences were aligned and compared to those in GenBank database using the NCBI BLAST algorithm (Altschul et al. 1997).

\section{Kerosene tolerance of Achromobacter and Pseudomonas strains}

\section{Solid medium overlay assay}

The tolerance of isolated bacteria to kerosene was determined by plate overlay assay (Satpute et al. 2008). Overnight cultures, grown in liquid LB medium at $30{ }^{\circ} \mathrm{C}$, 
were spotted $\left(20 \mu \mathrm{l}, \mathrm{OD}_{660} 0.3\right)$ onto $\mathrm{LB}$ agar plates, air dried, and then overlaid with kerosene (Sigma-Aldrich, Saint-Quentin-Fallavier, France). Control experiments were set up in the same way, but in the absence of kerosene. Here, as elsewhere in this work, the assays were done in duplicate. The plates with or without kerosene were incubated 1 day at $30{ }^{\circ} \mathrm{C}$. Kerosene tolerance was measured as a function of the bacterial growth (colony formation), as compared with the control. Here, as elsewhere in this work, the Petri plates were visualized under visible light $(500 \mathrm{~nm})$ and UV light (366 nm).

\section{Liquid medium overlay assay}

Overnight cultures grown in liquid LB medium at $30{ }^{\circ} \mathrm{C}$ were inoculated $\left(100-200 \mu \mathrm{l}, \mathrm{OD}_{660} 0.1\right)$ in liquid LB medium, and then overlaid with $5 \%(\mathrm{v} / \mathrm{v})$ kerosene. Control experiments were set up in the same way, but in the absence of kerosene. Flasks were incubated 1, 3, and 6 days at $30{ }^{\circ} \mathrm{C}$ on a rotary shaker $(200 \mathrm{rpm})$. The tolerance of isolated bacteria to kerosene was monitored by determining the optical density at $660 \mathrm{~nm}\left(\mathrm{OD}_{660}\right)$ using a SPECORD 200 UV-visible spectrophotometer (Analytik Jena, Jena, Germany), the cell viability by the spot method as described by Stancu (2018), and the biomass using the dry weight method (Silva et al. 2010). The degradation of kerosene by isolated bacteria was monitored by gravimetric analyses and by high-performance thinlayer chromatography (HPTLC) analyses of the residual kerosene extracted with chloroform (Gulati and Mehta 2017). HPTLC analyses were carried out using a CAMAG TLC system (Muttenz, Switzerland). The samples were loaded under nitrogen stream on precoated silica gel 60 plates (Merck, Darmstadt, Germany) and developed using $n$-hexane-ethyl acetate $(92: 8, \mathrm{v} / \mathrm{v})$ (Eberlin et al. 2009), methanol or $n$-hexane-ethyl acetatemethanol-water (40:20:20:4, v/v/v/v) as carrier solution. The plates were visualized and scanned under UV light $(254 \mathrm{~nm})$ and under visible light $(500 \mathrm{~nm})$ after derivatization with anisaldehyde solution (Eberlin et al. 2009).

\section{Secondary metabolites production by Achromobacter and Pseudomonas strains \\ Surfactants}

Production of extracellular surfactants was monitored by determining the cell growth and the formation of a dark blue halos on CTAB (cetyl trimethyl ammonium bromide) methylene blue agar (Siegmund and Wagner 1991), the emulsification index $\left(E_{24}\right)$ for kerosene (Abdel-Mawgoud et al. 2009), and by HPTLC analyses of the crude surfactants extracted with chloroformmethanol (Gesheva et al. 2010). HPTLC analyses were carried out using a CAMAG TLC system (Muttenz). The samples were loaded under nitrogen stream on precoated silica gel 60 plates (Merck) and developed using chloroform-methanol-water (65:25:4, v/v/v) as carrier solution (Gesheva et al. 2010). The plates were visualized and scanned under UV light $(254 \mathrm{~nm})$ and under visible light $(500 \mathrm{~nm})$ after derivatization with iodine vapors or orcinol solution (Gesheva et al. 2010).

Genomic DNA was extracted using Pure Link genomic kit (Invitrogen). PCR amplification of rhlAB gene was performed in a total reaction volume of $25 \mu \mathrm{l}$ using GoTaq G2 Flexi DNA polymerase (Promega) in the supplied buffer. The primers used were rhlA-f and rhlB-r (Medina et al. 2003). Amplifications were carried out in a Mastercycler pro S (Eppendorf) using the following program: initial denaturation at $94{ }^{\circ} \mathrm{C}$ for $10 \mathrm{~min}$, followed by 35 cycles of $94{ }^{\circ} \mathrm{C}$ for $1 \mathrm{~min}, 50{ }^{\circ} \mathrm{C}$ for $30 \mathrm{~s}$, and $72{ }^{\circ} \mathrm{C}$ for $2 \mathrm{~min}$, with final extension at $72{ }^{\circ} \mathrm{C}$ for 10 $\mathrm{min}$. Reaction products resolved by $1.5 \%(\mathrm{w} / \mathrm{v})$ agarose gel electrophoresis (Sambrook and Russel 2001) and stained with SYBR safe DNA gel stain (Invitrogen) were visualized under UV light.

\section{Pigments}

Production of extracellular pigments, such as pyocyanin and pyoverdin, was monitored by determining the formation of blue-green and yellow-green fluorescent colonies on King A and King B agar (King et al. 1954) and by HPTLC analyses of the pigments extracted with dichloromethane (Jensen et al. 2006). HPTLC analyses were carried out using a CAMAG TLC system (Muttenz). The samples were loaded under nitrogen stream on precoated silica gel 60 plates (Merck) and developed using dichloromethane-methanol $(95: 5, \mathrm{v} / \mathrm{v})$ as carrier solution (Jensen et al. 2006). The plates were visualized and scanned under UV light $(254 \mathrm{~nm})$. Pyocyanin extracted with chloroform and $0.2 \mathrm{~N} \mathrm{HCl}$ (Jensen et al. 2006) was quantified by UV-visible (200-800 nm) spectroscopy analyses (El-Fouly et al. 2015) using a SPECORD 200 UV-visible spectrophotometer (Analytik Jena).

Production of intracellular pigments, such as carotenoid pigments, was monitored by determining the formation of creamy colonies on LB or King B agar and by HPTLC analyses of the pigments extracted with acetone (Beuttler et al. 2011). HPTLC analyses were carried out using a CAMAG TLC system (Muttenz). The samples were loaded under nitrogen stream on precoated silica gel 60 plates (Merck) and developed using chloroformmethanol $(90: 10, v / v)$ as carrier solution (Provvedi et al. 2008). The plates were visualized and scanned under UV light $(254 \mathrm{~nm})$. Production of carotenoid pigments, such as zeaxanthin, was confirmed by UV-visible (200-800 $\mathrm{nm}$ ) spectroscopy analyses of crude extracts (Beuttler et al. 2011) using a SPECORD 200 UV-visible spectrophotometer (Analytik Jena). 


\section{Results and discussion}

Isolation and characterization of Achromobacter and Pseudomonas strains

As a result of very low growth rate of many bacteria which exist in petroleum and petroleum product-polluted environments, less than $1 \%$ of the bacteria are cultivable in laboratory conditions. Thus, only fast growing or the best adapted bacteria are cultivable in laboratory conditions (Chikere et al. 2011). Using a culture-dependent approach, we succeed to isolate five bacterial strains from different samples polluted with petroleum and petroleum products. Strain $\mathrm{IBB}_{\mathrm{Po18}}$ was isolated from a water sample, strains $\mathrm{IBB}_{\mathrm{Po19}}$ and $\mathrm{IBB}_{\mathrm{Po} 20}$ were isolated from a soil sample, while strains $\mathrm{IBB}_{\mathrm{P} 212}$ and $\mathrm{IBB}_{\mathrm{Po} 22}$ were isolated from a oily sludge sample.

Distinct morphological and biochemical characteristics were observed for the isolated bacteria (Table 1, Fig. 1). Strains $\mathrm{IBB}_{\mathrm{Po18}}, \mathrm{IBB}_{\mathrm{Po19}}$, and $\mathrm{IBB}_{\mathrm{Po} 21}$ formed creamywhite pigmented colonies, while strains $\mathrm{IBB}_{\mathrm{Po} 20}$ and $\mathrm{IBB}_{\mathrm{Po} 22}$ formed yellow-green pigmented colonies on LB agar. All isolates were Gram-negative, motile, rod-shaped cells, and facultative anaerobic. They were positive for catalase, oxidase, L-arginine dihydrolase, D-glucose, potassium gluconate, capric acid, malic acid, and for trisodium citrate assimilation and negative for lactose, indole, Dglucose fermentation, esculin hydrolysis, $\beta$-galactosidase, and for D-maltose assimilation. Furthermore, the isolated bacteria were positive or negative for nitrate reductase, urease, gelatin hydrolysis, L-arabinose, D-mannose, Dmannitol, N-acetyl-glucosamine, adipic acid, and for phenylacetic acid assimilation. Based on morphological and biochemical characteristics, all isolates were classified within the genus Achromobacter and Pseudomonas.

The DNA extracted from isolated bacteria was used as template for PCR amplification of 16S rRNA gene using universal bacterial primers, such as $27 \mathrm{f}$ and 1492r (Marchesi et al. 1998). The conserved fragment of the $16 \mathrm{~S}$ rRNA gene with 1465 bp in length was detected in all isolates (Table 1, Fig. 1). ARDRA analyses were carried out on the amplified fragment with EcoRI, HaeIII, and HhaI restriction enzymes. Two ARDRA profiles were obtained when the amplified fragment was digested with EcoRI: one group composed of $\mathrm{IBB}_{\mathrm{Po} 18}$ and $\mathrm{IBB}_{\mathrm{Po} 21}$ isolates, and the second group composed of $\mathrm{IBB}_{\mathrm{Po1}}$, $\mathrm{IBB}_{\mathrm{Po} 20}$, and $\mathrm{IBB}_{\mathrm{Po} 22}$ isolates. When the amplified fragment was digested with HaeIII and HhaI, three ARDRA profiles were obtained: one group composed of $\mathrm{IBB}_{\mathrm{Po} 18}$ and $\mathrm{IBB}_{\mathrm{Po} 21}$ isolates, the second group composed of $\mathrm{IBB}_{\mathrm{Po19}}$ isolate, and the third group composed of $\mathrm{IBB}_{\mathrm{Po} 20}$ and $\mathrm{IBB}_{\mathrm{Po} 22}$ isolates.

For further characterization of the isolated bacteria, DNA extracted from all of them was used as template for RAPD analyses using primers AP12 (Michaud et al. 2004) and AP5 (Pini et al. 2007). As expected, three distinct RAPD profiles were observed: one group composed of $\mathrm{IBB}_{\mathrm{Po} 18}$ and $\mathrm{IBB}_{\mathrm{Po} 21}$ isolates, the second group composed of $\mathrm{IBB}_{\mathrm{Po19}}$ isolate, and the third group composed of $\mathrm{IBB}_{\mathrm{Po} 20}$ and $\mathrm{IBB}_{\mathrm{Po} 22}$ isolates.

The ARDRA and RAPD analyses revealed that the five isolates produced three different DNA fingerprints. Strains $\mathrm{IBB}_{\mathrm{Po} 18}, \mathrm{IBB}_{\mathrm{Po19}}$, and $\mathrm{IBB}_{\mathrm{Po} 22}$ which exhibited different DNA fingerprints were chosen for $16 \mathrm{~S}$ rRNA gene sequence analyses. The sequences of $\mathrm{IBB}_{\mathrm{Po} 18}$ (MK934546), IBB IBo19 (MK934547), and IBB $_{\text {Po22 }}$ (MK934548) isolates were 98-100\% similar to the $16 \mathrm{~S}$ rRNA gene sequences of $A$. spanius UQ283 (CP034689.1), P. putida YM9 (MK634690.1), and P. aeruginosa PsADMC06 (MK598332.1), respectively. Based on morphological, biochemical, and molecular characteristics, strains $\mathrm{IBB}_{\mathrm{Po} 18}$ and $\mathrm{IBB}_{\mathrm{Po} 21}$ were classified within the species $A$. spanius, strain $\mathrm{IBB}_{\mathrm{Po} 19}$ was classified within the species $P$. putida, while strains $\mathrm{IBB}_{\mathrm{Po} 20}$ and $\mathrm{IBB}_{\mathrm{Po} 22}$ were classified within the species $P$. aeruginosa. Two of the isolates (i.e., A. spanius $\mathrm{IBB}_{\mathrm{Po} 18}$ and $\mathrm{IBB}_{\mathrm{Po} 21}$ ) belonged to class Betaproteobacteria, while the other three isolates (i.e., P. putida $\mathrm{IBB}_{\mathrm{Po19}}$, P. aeruginosa $\mathrm{IBB}_{\mathrm{Po} 20}$ and $\mathrm{IBB}_{\mathrm{Po} 22}$ ) were from class Gammaproteobacteria. Occurrence of these Proteobacteria in environments polluted with petroleum and petroleum products have been previously reported (Joy et al. 2017).

\section{Kerosene tolerance of Achromobacter and Pseudomonas strains}

The tolerance of Achromobacter and Pseudomonas isolates to kerosene was further investigated in both solid and liquid media.

\section{Solid medium plate overlay assay}

The ability of the isolated bacteria to tolerate kerosene was first determined by plate overlay assay (Fig. 2a). Lower growth was observed for A. spanius $\mathrm{IBB}_{\mathrm{Po} 18}$ and $\mathrm{IBB}_{\mathrm{Po} 21}$ and $P$. putida $\mathrm{IBB}_{\mathrm{Po} 19}$ when they were spotted on LB agar overlaid or not with kerosene, compared with that observed for $P$. aeruginosa $\mathrm{IBB}_{\mathrm{Po} 20}$ and $\mathrm{IBB}_{\mathrm{P} \text { 22 }}$ which showed profuse growth on the kerosene overlay plates. It was not surprising to observe such differences from one bacterium to another, as the tolerance of bacteria to toxic hydrocarbons is a strain-specific characteristic (Sardessai and Bhosle 2004). If we compare the growth of each Achromobacter and Pseudomonas isolates with their corresponding control, there were no significant differences between bacteria growth on LB agar and their growth on LB overlaid with kerosene. Usually, the tolerance level derived from the growth on nutrient agar media overlaid with hydrocarbons could be different from that observed in two-phase biotransformation systems consisting of a liquid nutrient medium and a hydrocarbon. Several additional parameters, such as 
Table 1 Morphological, biochemical, and molecular characteristics of Achromobacter and Pseudomonas strains

\begin{tabular}{|c|c|c|c|c|c|c|}
\hline \multicolumn{2}{|l|}{ Characteristics } & \multicolumn{5}{|l|}{ Strain } \\
\hline & & $\mathrm{IBB}_{\mathrm{Po18}}$ & $\mathrm{IBB}_{\mathrm{P} 019}$ & $\mathrm{IBB}_{\mathrm{Po} 20}$ & $\mathrm{IBB}_{\mathrm{PO} 21}$ & $\mathrm{IBB}_{\mathrm{PO} 22}$ \\
\hline \multirow{30}{*}{$\begin{array}{l}\text { Morphological, } \\
\text { biochemical }\end{array}$} & Gram & - & - & - & - & - \\
\hline & Shape & Rods & Rods & Rods & Rods & Rods \\
\hline & Motility & + & + & + & + & + \\
\hline & Color of colonies & Creamy-white & Creamy-white & Yellow-green & Creamy-white & Yellow-green \\
\hline & Pyocyanin pigment production & - & - & + & - & + \\
\hline & Pyoverdin pigment production & - & - & + & - & - \\
\hline & Facultative anaerobic growth & + & + & + & + & + \\
\hline & Catalase & + & + & + & + & + \\
\hline & Oxidase & + & + & + & + & + \\
\hline & Lactose utilization & - & - & - & - & - \\
\hline & Nitrates reduction & + & - & + & + & + \\
\hline & Indole & - & - & - & - & - \\
\hline & D-glucose fermentation & - & - & - & - & - \\
\hline & L-arginine dihydrolase & + & + & + & + & + \\
\hline & Urease & - & - & + & - & + \\
\hline & Esculin hydrolysis & - & - & - & - & - \\
\hline & Gelatin hydrolysis & - & - & + & - & + \\
\hline & $\beta$-galactosidase & - & - & - & - & - \\
\hline & D-glucose assimilation & + & + & + & + & + \\
\hline & L-arabinose assimilation & + & + & - & + & - \\
\hline & D-mannose assimilation. & + & + & - & + & - \\
\hline & D-mannitol assimilation & + & - & + & + & + \\
\hline & N-acetyl-glucosamine assimilation & - & - & + & - & + \\
\hline & D-maltose assimilation & - & - & - & - & - \\
\hline & Potassium gluconate assimilation & + & + & + & + & + \\
\hline & Capric acid assimilation & + & + & + & + & + \\
\hline & Adipic acid assimilation & + & - & + & + & + \\
\hline & Malic acid assimilation & + & + & + & + & + \\
\hline & Trisodium citrate assimilation & + & + & + & + & + \\
\hline & Phenylacetic acid assimilation & + & + & - & - & - \\
\hline \multirow[t]{9}{*}{ Molecular } & ARDRA using & & & & & \\
\hline & 27f/1492r primers (DFS, bp) & 1465 & 1465 & 1465 & 1465 & 1465 \\
\hline & EcoRl restriction enzyme (DFS, bp) & $370,520,700$ & - & - & $370,520,700$ & - \\
\hline & $\begin{array}{l}\text { Haelll, thal restriction enzymes } \\
\text { (DFS, bp) }\end{array}$ & 300,350 & $150,200,340,430$ & $150,200,350$ & 300,350 & $150,200,350$ \\
\hline & RAPD using & & & & & \\
\hline & AP12 primer (DFS, bp) & $400-2400$ & $390-3000$ & $360-3000$ & $400-2400$ & $360-3000$ \\
\hline & AP5 primer (DFS, bp) & 300-1900 & $480-2000$ & $270-1450$ & $350-2500$ & $280-1600$ \\
\hline & $\begin{array}{l}165 \text { rRNA gene sequence, } \\
\text { sequence identity (\%) }\end{array}$ & A. spanius, 99 & P. putida, 98 & P. aeruginosa, ND & A. spanius, ND & P. aeruginosa, 100 \\
\hline & GenBank accession number & MK934546 & MK934547 & - & - & MK934548 \\
\hline
\end{tabular}



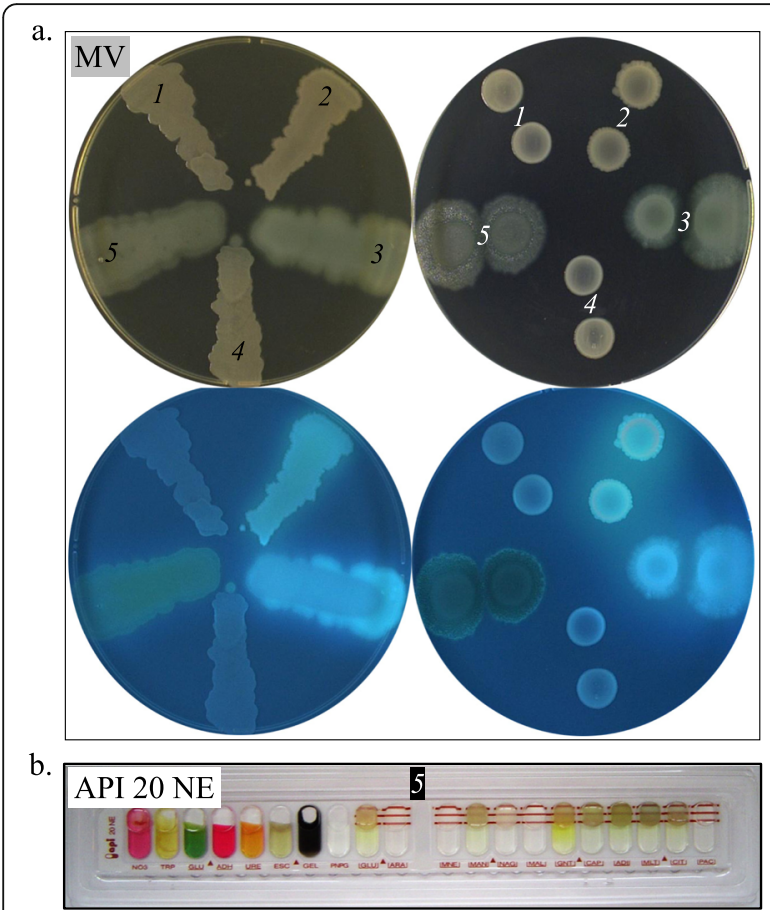
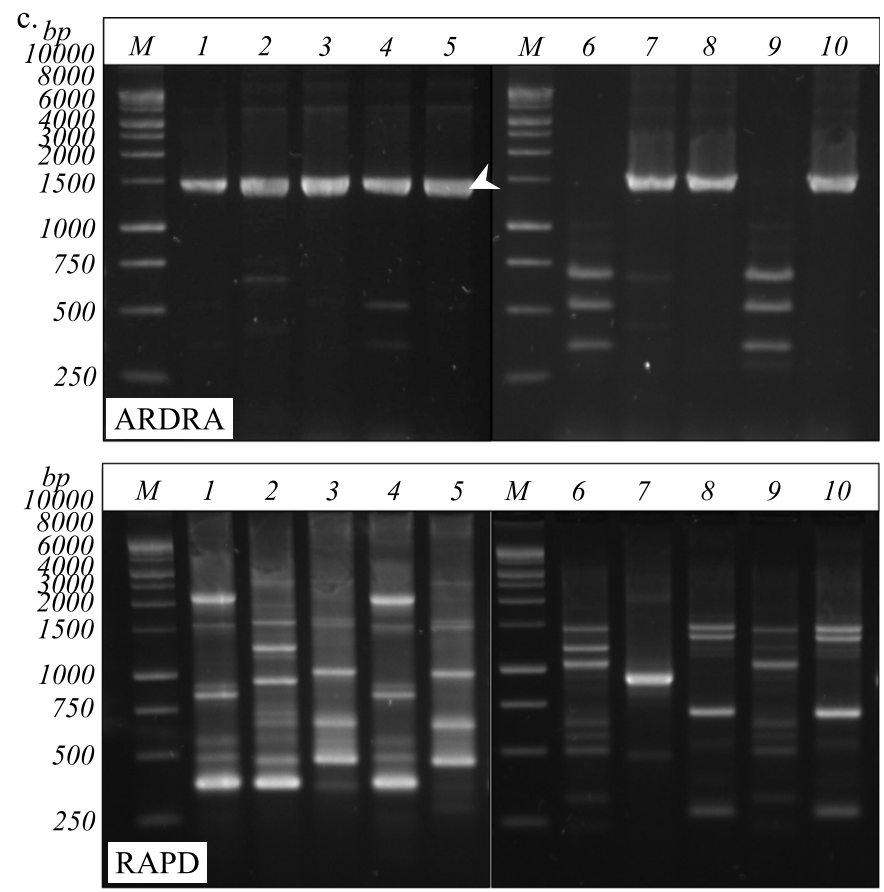

Fig. 1 Morphological, biochemical and molecular characteristics of Achromobacter and Pseudomonas strains. a Macroscopic view (MV): A. spanius

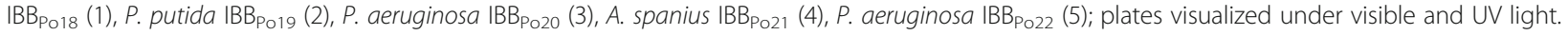
b Utilization of several carbon substrates using API 20 NE plates. c Genomic fingerprinting: A. spanius IBB po18 (1, 6), P. putida IBB Po19 (2, 7), P. aeruginosa IBB Po20 $(3,8)$, A. spanius IBB Po21 $(4,9)$, P. aeruginosa IBB po22 $_{2}(5,10)$; ARDRA PCR of 165 rRNA gene (1465 bp fragment) using 27f/1492r primers (1-5), digestion of the amplified fragment with EcoRI restriction enzyme (6-10); RAPD using AP12 (1-5), AP5 (6-10) primers; 1 kb DNA ladder, Promega (M)
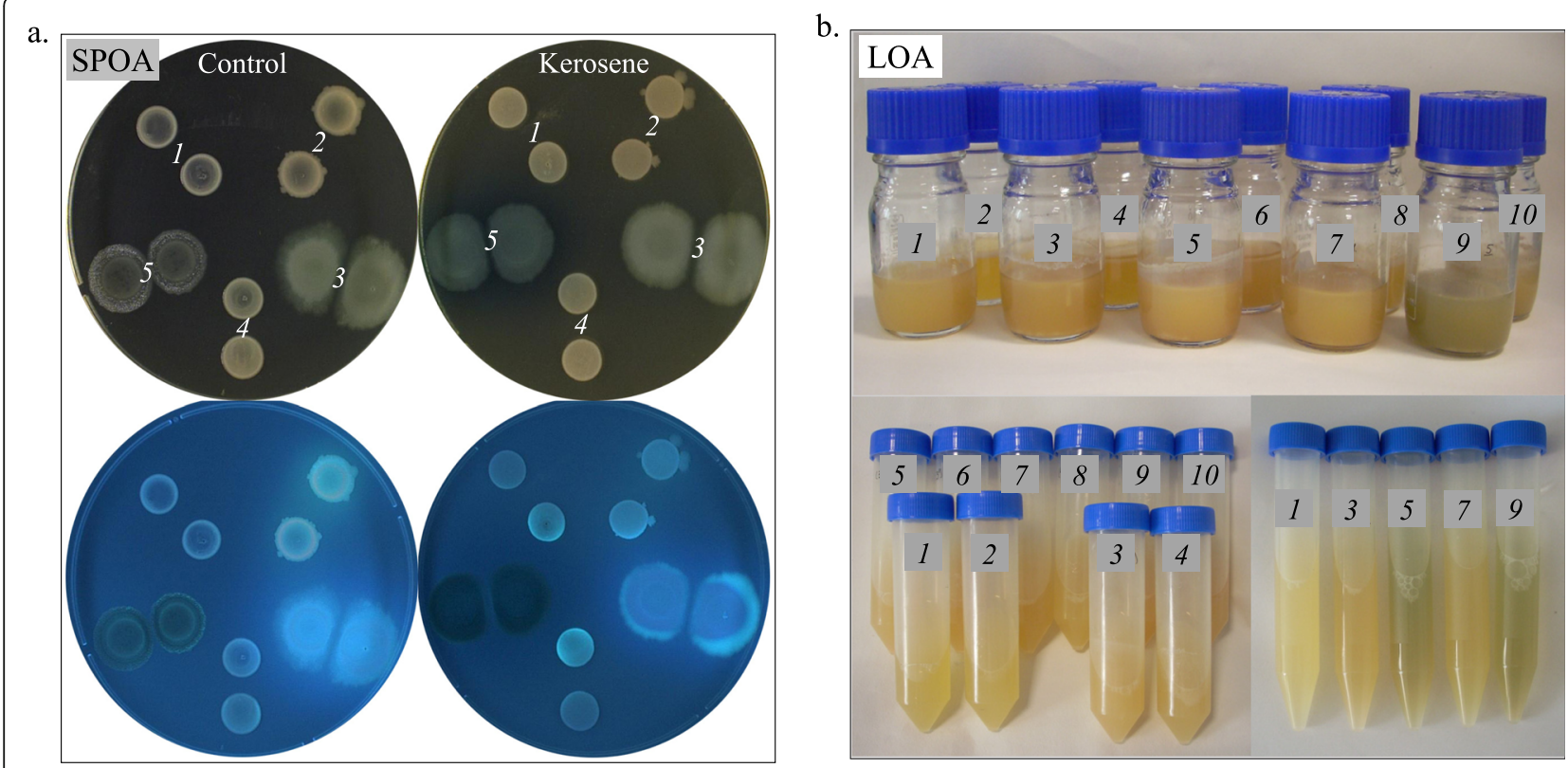

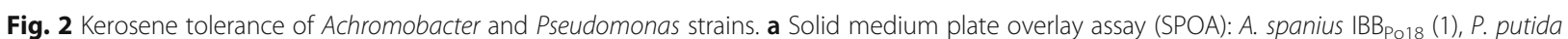

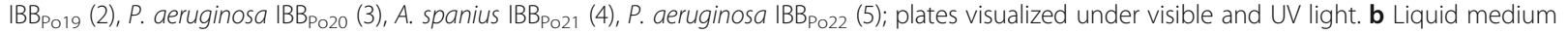

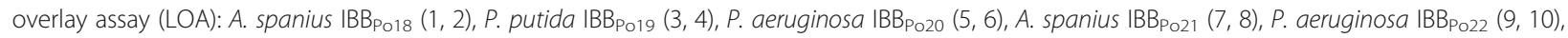
control $(1,3,5,7,9)$, kerosene $(2,4,6,8,10)$ 
aeration, may possibly be involved in hydrocarbons tolerance in such two-phase systems (Sardessai and Bhosle 2004).

\section{Liquid medium overlay assay}

We further investigated the ability of the isolated bacteria to tolerate kerosene when they were inoculated in liquid LB medium overlaid with $5 \%$ kerosene (Fig. 2b, Fig. $3 \mathrm{a}-\mathrm{c})$. All tested bacteria were able to grow in the presence of kerosene. After 1 and 3 days incubation, the growth of Achromobacter and Pseudomonas isolates in liquid LB medium overlaid or not with kerosene was lower $\left(\mathrm{OD}_{660}\right.$ 0.31-1.27) (data not shown), compared with that acquired after 6 days $\left(\mathrm{OD}_{660} 1.39-2.45\right)$ (Fig. $3 \mathrm{~b})$. We observed that, after 6 days, the growth of $A$. spanius $\mathrm{IBB}_{\mathrm{Po} 18}$ and $\mathrm{IBB}_{\mathrm{P} 021}$ and $P$. putida $\mathrm{IBB}_{\mathrm{Po} 19}$ in liquid LB medium was lower for the control cells $\left(\mathrm{OD}_{660}\right.$ 1.39-2.03), compared with the growth of the cells in the same medium but overlaid with kerosene $\left(\mathrm{OD}_{660} 2.12\right.$ 2.45). On the contrary, for $P$. aeruginosa $\mathrm{IBB}_{\mathrm{Po} 20}$ and $\mathrm{IBB}_{\mathrm{Po} 22}$, the growth was higher for the control cells $\left(\mathrm{OD}_{660} 2.27,2.04\right)$, compared with the growth of the cells in the presence of kerosene $\left(\mathrm{OD}_{660} 2.17,1.89\right)$. The same trend was observed when the bacterial biomass was determined. The dry weight values for $A$. spanius $\mathrm{IBB}_{\mathrm{Po} 18}$ and $\mathrm{IBB}_{\mathrm{Po} 21}$ and $P$. putida $\mathrm{IBB}_{\mathrm{Po} 19}$ control cells was lower $\left(0.58-1.38 \mathrm{~g} \mathrm{l}^{-1}\right)$, compared with those aquired when these bacteria were grown in the presence of kerosene (1.04-1.50 $\mathrm{g} \mathrm{l}^{-1}$ ). Higher dry weight values were obtained for $P$. aeruginosa $\mathrm{IBB}_{\mathrm{Po} 20}$ and $\mathrm{IBB}_{\mathrm{Po} 22}$ control cells $\left(1.76,1.66 \mathrm{~g} \mathrm{l}^{-1}\right)$, compared with those obtained when these bacteria were grown in the presence of kerosene $\left(1.71,1.56 \mathrm{~g} \mathrm{l}^{-1}\right)$. Like in the solid medium plate overlay assay, lower growth was observed for $A$. spanius $\mathrm{IBB}_{\mathrm{Po} 18}$ and $\mathrm{IBB}_{\mathrm{Po} 21}$ and P. putida $\mathrm{IBB}_{\mathrm{Po} 19}$ when they were spotted on LB agar, compared with that observed for $P$. aeruginosa $\mathrm{IBB}_{\mathrm{Po} 20}$ and $\mathrm{IBB}_{\mathrm{Po} 22}$. There were no significant differences between the viability of control cells (confluent cell growth) and the viability of cells grown in the presence of kerosene. The obtained results indicated that the tested bacteria have a good tolerance to kerosene.

Using gravimetric analyses, we further investigated the ability of our bacteria to degrade $5 \%$ kerosene (Fig. 3d, e). After 6 days, the degradation of kerosene by $A$. spanius $\mathrm{IBB}_{\mathrm{Po} 18}$ and $\mathrm{IBB}_{\mathrm{Po} 21}$ and $P$. putida $\mathrm{IBB}_{\mathrm{Po19}}$ was lower (42.0-44.7\%), compared with that observed for $P$. aeruginosa $\mathrm{IBB}_{\mathrm{P} o 20}$ and $\mathrm{IBB}_{\mathrm{Po} 22}(54.2 \%, 56.9 \%)$. It was

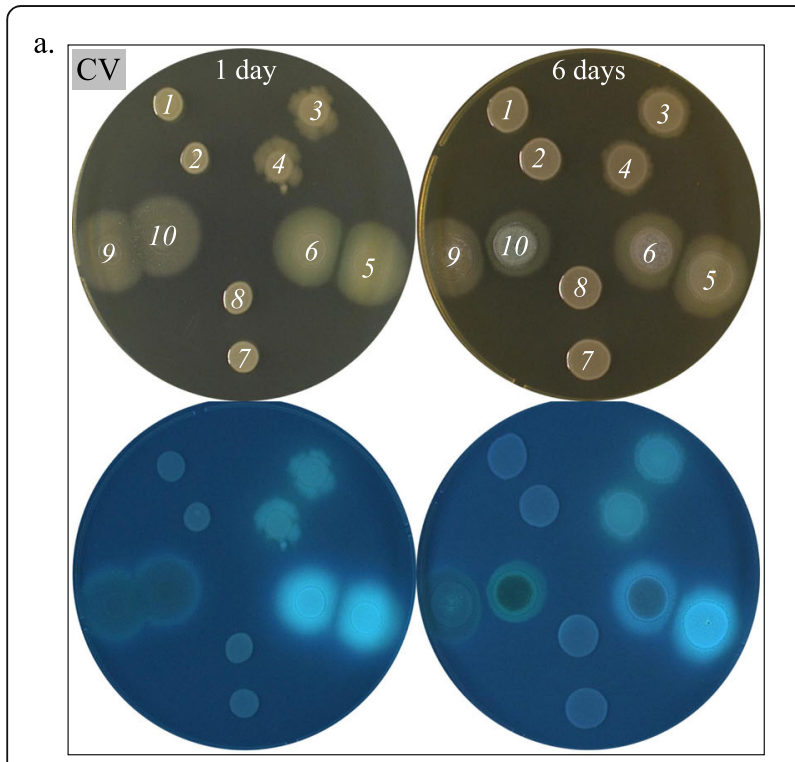

b.

\begin{tabular}{|l|c|c|c|c|c|}
\hline OD $_{660} 6$ days & \multicolumn{5}{|c|}{ Strain } \\
\cline { 2 - 6 }$(\mathrm{nm} \pm \mathrm{SD})$ & $\mathrm{IBB}_{\text {Po18 }}$ & $\mathrm{IBB}_{\text {Po19 }}$ & $\mathrm{IBB}_{\text {P020 }}$ & $\mathrm{IBB}_{\text {Po21 }}$ & $\mathrm{IBB}_{\text {Po22 }}$ \\
\hline \multirow{2}{*}{ Control } & $1.54 \pm$ & $2.03 \pm$ & $2.27 \pm$ & $1.39 \pm$ & $2.04 \pm$ \\
& 0.01 & 0.07 & 0.05 & 0.05 & 0.08 \\
\hline \multirow{2}{*}{ Kerosene } & $2.12 \pm$ & $2.45 \pm$ & $2.17 \pm$ & $2.25 \pm$ & $1.89 \pm$ \\
& 0.11 & 0.16 & 0.05 & 0.19 & 0.10 \\
\hline
\end{tabular}

c.

\begin{tabular}{|c|c|c|c|c|c|}
\hline \multirow{2}{*}{$\mathrm{DW} 6$ days } & \multicolumn{5}{|c|}{ Strain } \\
\cline { 2 - 6 }$\left(\mathrm{g} \mathrm{l}^{-1} \pm \mathrm{SD}\right)$ & $\mathrm{IBB}_{\text {Po18 }}$ & $\mathrm{IBB}_{\text {Po19 }}$ & $\mathrm{IBB}_{\text {Po20 }}$ & $\mathrm{IBB}_{\text {Po21 }}$ & $\mathrm{IBB}_{\text {Po22 }}$ \\
\hline \multirow{2}{*}{ Control } & $0.58 \pm$ & $1.38 \pm$ & $1.76 \pm$ & $0.60 \pm$ & $1.66 \pm$ \\
& 0.01 & 0.04 & 0.07 & 0.01 & 0.02 \\
\hline \multirow{2}{*}{ Kerosene } & $1.04 \pm$ & $1.50 \pm$ & $1.71 \pm$ & $1.46 \pm$ & $1.56 \pm$ \\
& 0.08 & 0.07 & 0.07 & 0.07 & 0.03 \\
\hline
\end{tabular}

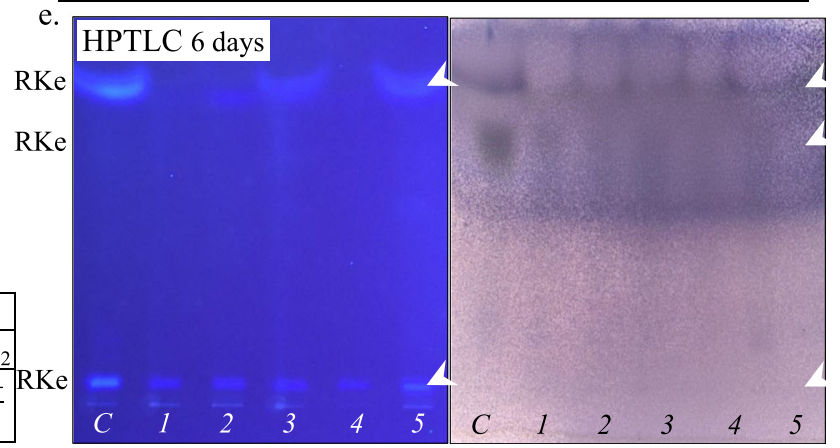

d.

\begin{tabular}{|c|c|c|c|c|c|}
\hline DKe 6 days & \multicolumn{5}{|c|}{ Strain } \\
\cline { 2 - 6 }$(\% \pm \mathrm{SD})$ & $\mathrm{IBB}_{\mathrm{P} 018}$ & $\mathrm{IBB}_{\mathrm{P} 019}$ & $\mathrm{IBB}_{\mathrm{P} 020}$ & $\mathrm{IBB}_{\mathrm{P} 021}$ & $\mathrm{IBB}_{\mathrm{P} 022}$ \\
\hline \multirow{2}{*}{ Kerosene } & $42.0 \pm$ & $44.7 \pm$ & $54.2 \pm$ & $43.2 \pm$ & $56.9 \pm$ \\
& 0.15 & 0.17 & 0.09 & 0.10 & 0.11 \\
\hline
\end{tabular}

Fig. 3 Tolerance to kerosene and their degradation by Achromobacter and Pseudomonas strains. a Cell viability (CV): A. spanius IBBPo18 (1, 2), P.

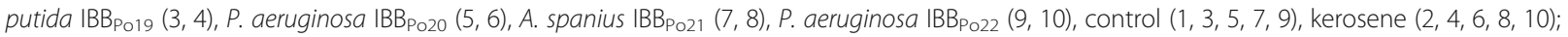
plates visualized under visible and UV light. b Optical density $\left(\mathrm{OD}_{660}\right)$. c Dry weight (DW). d Degradation of kerosene (DKe). The values represent the average from two independent assays ( $\mathrm{nm}, \mathrm{g} \mathrm{I} \mathrm{I}^{-1}$ or \%) with standard deviation (SD). e HPTLC: A. spanius IBBpo18 (1), P. putida IBBpo19 (2), P.

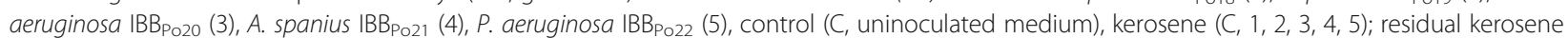
(RKe); plate visualized and scanned under UV and visible light 
not surprising to observe these differences since $P$. aeruginosa strains are the best known bacteria able to utilize a number of aliphatic and aromatic hydrocarbons as the carbon and energy sources (Pacwa-Płociniczak et al. 2014). The ability of other Achromobacter (Mazumdar et al. 2015) and Pseudomonas (Silva et al. 2006; Ahamed et al. 2010) strains to grow on kerosene as the carbon and energy source was earlier reported. Achromobacter sp. $\mathrm{AM}_{05}$ degraded all the major components of kerosene in 60 days (Mazumdar et al. 2015), while P. alcaligenes F.S3b degraded $0.2 \%$ kerosene in a percent of $76.08 \%$ in 7 days (Ahamed et al. 2010). Silva et al. (2006) reported that the maximum growth $\left(2.5 \mathrm{~g} \mathrm{l}^{-1}\right)$ for $P$. aeruginosa strain AT18 was in $0.2 \%$ kerosene. As observed, our Achromobacter and Pseudomonas strains degraded $5 \%$ kerosene in 6 days with good degradation rates (42.0-56.9\%). The degradation of kerosene by the tested bacteria was also confirmed by HPTLC analyses of the residual kerosene extracts. As we described in the "Materials and methods" section, several carrier solution were tested and the best one was n-hexane-ethyl acetate-methanol-water mixture (Fig. 3e). When the TLC plate was visualized under UV light, the control (uninoculated medium overlaid with kerosene) gave two spots at the $R_{\mathrm{f}}$ (retardation factor) value of 0.06 and 0.80 . These two spots were also detected in extracts from the tested bacteria grown in the presence of kerosene. When the TLC plate was derivatized with anisaldehyde solution and visualized under visible light, an additional spot with the $R_{\mathrm{f}}$ value of 0.66 was detected in the control, while in the extracts from the tested bacteria, this spot was detected only in barely quantities. The presence of these three spots in lower quantities in extracts from the inoculated medium overlaid with kerosene indicates the degradation of some hydrocarbons which exist in the composition of kerosene by tested bacteria.

\section{Secondary metabolites production by Achromobacter and Pseudomonas strains}

The ability of the isolated bacteria to produce secondary metabolites such as surfactants and pigments when they were inoculated in liquid LB medium overlaid or not with $5 \%$ kerosene was also investigated in this study.

\section{Surfactants}

One of the numerous physiological adaptations of bacteria induced by presence of hydrocarbons is surfactant production (Joy et al. 2017), which could be present on the cell surface and/or excreted extracellularly (Rikalović et al. 2015). The ability of the isolated bacteria to produce extracellular surfactants was confirmed by $\mathrm{CTAB}$ methylene blue agar assay (Fig. 4a). All tested bacteria were able to grow on CTAB methylene blue agar. No significant differences were observed between the growth of control cells and that observed for the cells grown in the presence of kerosene. After 6 days, lower growth on CTAB methylene blue agar was observed for $A$. spanius $\mathrm{IBB}_{\mathrm{Po} 18}$ and $\mathrm{IBB}_{\mathrm{Po} 21}$ and P. putida $\mathrm{IBB}_{\mathrm{Po} 19}$, compared with $P$. aeruginosa $\mathrm{IBB}_{\mathrm{Po} 20}$ and $\mathrm{IBB}_{\mathrm{Po} 22}$. Although all tested bacteria grew on $C T A B$ methylene blue agar, the formation of a dark blue halo around the colony (which indicates the production of the extracellular glycolipids or other anionic surfactants) was observed only for $P$. aeruginosa $\mathrm{IBB}_{\mathrm{Po} 20}$ and $\mathrm{IBB}_{\mathrm{Po} 22}$. An increase in biosurfactant production was observed for $P$. aeruginosa $\mathrm{IBB}_{\mathrm{P} 20}$ and $\mathrm{IBB}_{\mathrm{P} \text { 222 }}$ after 6 days incubation, compared with that observed after 1 and 3 days. Our results are in agreement with that earlier reported concerning the overproduction of glycolipid surfactants by $P$. aeruginosa strains during nutrient limitation conditions (Chrzanowski et al. 2012).

As could be observed (Fig. 4b), Achromobacter and Pseudomonas isolates were able to produce surfactants that emulsify the kerosene, and these tension-active compounds have very good emulsification activities $\left(E_{24}\right.$ of 57-94\%). Mnif et al. (2011) and Joy et al. (2017) reported the isolation of other Achromobacter (i.e., A. xylosoxidans C350R, Achromobacter sp. PS1) and Pseudomonas (i.e., P. aeruginosa C450R, Pseudomonas sp. MRBSIT1) strains with very good emulsification activities ( $E_{24}$ of $\left.45-77 \%\right)$. We observed an increase in the emulsification activity ( $E_{24}$ of $\left.69-94 \%\right)$ when Achromobacter and Pseudomonas isolates were grown in the presence of kerosene, as compared with their coresponding controls $\left(E_{24}\right.$ of $\left.57-86 \%\right)$. The increase in the emulsification activity could be due to the biosurfactant production which has the ability to emulsify the hydrophobic compounds, such as hydrocarbons, and make them more accessible for bacterial degradation (Mnif et al. 2011).

The production of extracellular glycolipid surfactants by the isolated bacteria was confirmed by HPTLC analyses of the crude extracts. When the TLC plate was visualized under UV light (Fig. 4c), several surfactant fractions were observed for Achromobacter and Pseudomonas isolates, and the number of these fractions varies from one bacterium to another, and even for the same bacterium depending on the culture conditions (growth in liquid medium overlaid or not with kerosene). Between two and four fractions with $\mathrm{Rf}$ values of $0.41-0.62$ were detected in extracts from $A$. spanius $\mathrm{IBB}_{\mathrm{Po} 18}$ and $\mathrm{IBB}_{\mathrm{Po} 21}, P$. putida $\mathrm{IBB}_{\mathrm{Po} 19}$, and $P$. aeruginosa $\mathrm{IBB}_{\mathrm{Po} 20}$ and $\mathrm{IBB}_{\mathrm{Po} 22}$. From all these fractions, only two of them, those with $R_{\mathrm{f}}$ values of $0.46-0.48$ and $0.51-0.53$, were detected in all bacteria. When the same TLC plate was derivatized with iodine vapors or orcinol solution and visualized under visible light (data not shown), some of 

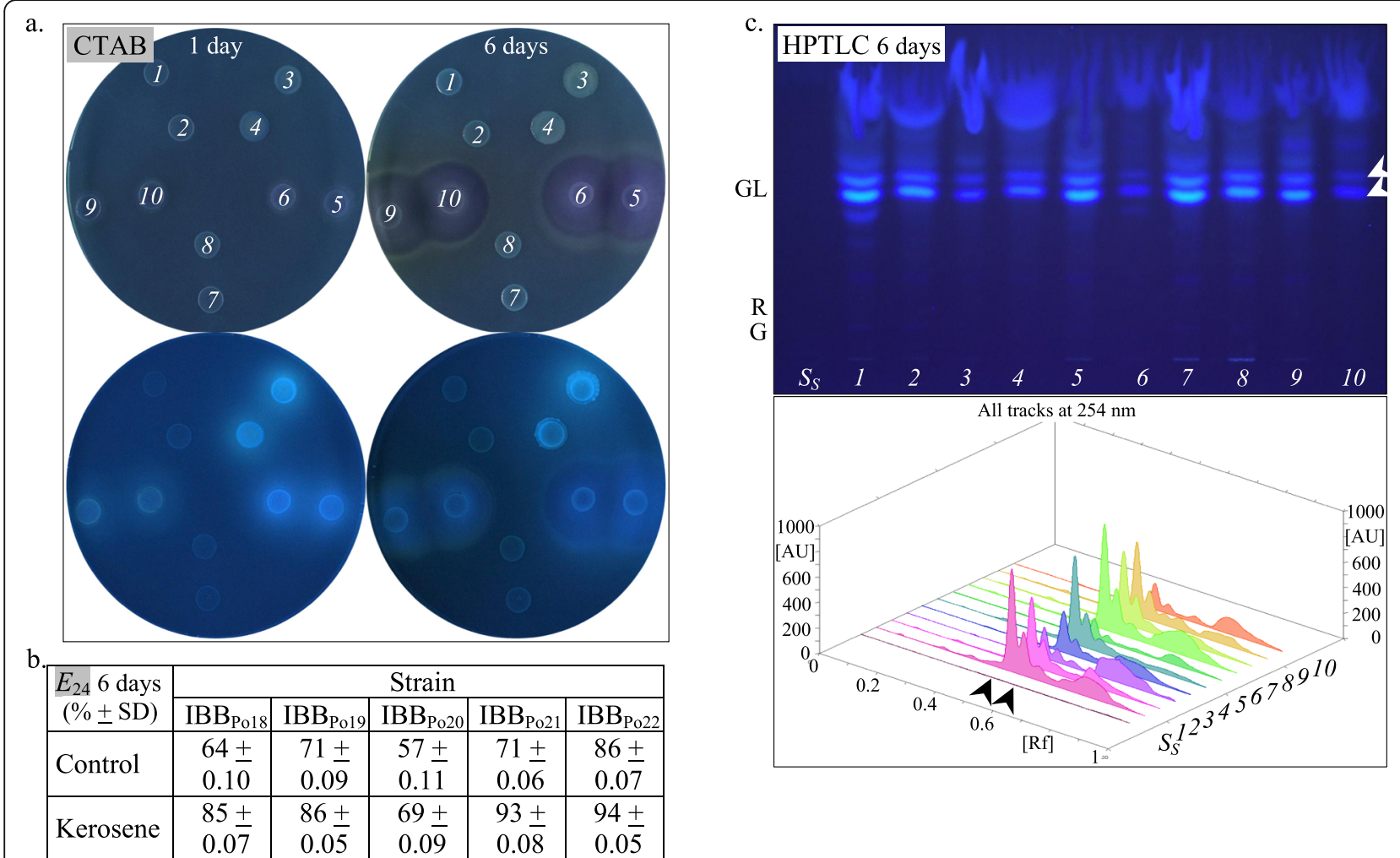

Fig. 4 Extracellular surfactant production by Achromobacter and Pseudomonas strains. a CTAB methylene blue assay: A. spanius IBB Po18 (1, 2), P.

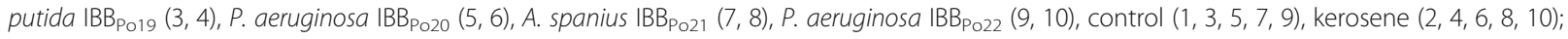
plates visualized under visible and UV light. $\mathbf{b} E_{24}$ (emulsification) index. The values represent the average from two independent assays (\%) with standard deviation (SD). c HPTLC: A. spanius IBBpo18 $(1,2)$, P. putida IBB po19 $(3,4)$, P. aeruginosa IBB po20 (5, 6), A. spanius IBBpo21 (7, 8), P. aeruginosa $\operatorname{IBB}_{\text {Po22 }}(9,10)$, control $(1,3,5,7,9)$, kerosene $(2,4,6,8,10)$; sugars standards $\left(S_{S}\right)$, D-glucose $(G)$, L-rhamnose $(R)$, glycolipids $(G L)$; plate visualized and scanned under UV light

these spots showed positive reaction indicating the presence of lipids and glycolipids in the surfactant molecules. The HPTLC analyses confirmed that surfactants produced by Achromobacter and Pseudomonas isolates are glycolipids; however, on the CTAB methylene blue agar assay, the formation of a dark blue halo around the colony was observed only for $P$. aeruginosa isolates. Like other Pseudomonas strains (e.g., $P$. aeruginosa, $P$. putida) (Rikalović et al. 2015), our Pseudomonas isolates (P. putida $\mathrm{IBB}_{\mathrm{Po} 19}$, P. aeruginosa $\mathrm{IBB}_{\mathrm{Po} 20}$ and $\mathrm{IBB}_{\mathrm{Po} 22}$ ) produced glycolipid surfactants, which are probably rhamnolipids in the case of $P$. aeruginosa isolates. Furthermore, surfactants produced by Achromobacter isolates $\left(A\right.$. spanius $\mathrm{IBB}_{\mathrm{Po18}}$ and $\mathrm{IBB}_{\mathrm{Po} 21}$ ) are also glycolipids. Similarly, Joy et al. (2017) reported glycolipid surfactant production by Achromobacter sp. PS1.

Another assay for the determination of the ability of the isolated bacteria to produce surfactants is the detection of enzyme-encoding genes involved in their biosynthesis (Pacwa-Płociniczak et al. 2014). Since all Achromobacter and Pseudomonas isolates were able to produce glycolipid surfactants, we further checked the presence of $\operatorname{rhl} A B$ (rhamnosyl transferase) gene in their genome. DNA extracted from bacteria grown 1 and 6 days in liquid LB medium overlaid or not with $5 \%$ kerosene was used as template for PCR amplification of $\operatorname{rhlAB}$ gene (Fig $5 \mathrm{a}, \mathrm{b}$ ) using primers rhlA-f and rhlB-r (Medina et al. 2003). As expected, the fragment of the rhlAB gene with $216 \mathrm{bp}$ in length was detected in higher quantities only in the DNA extracted from $P$. aeruginosa $\mathrm{IBB}_{\mathrm{Po} 20}$ and $\mathrm{IBB}_{\mathrm{Po} 22}$; no significant changes in their PCR pattern were observed. On the contrary, in the DNA extracted from $A$. spanius $\mathrm{IBB}_{\mathrm{Po18}}$ and $\mathrm{IBB}_{\mathrm{Po} 21}$, the rhlAB gene was detected in barely quantities and changes in their PCR pattern were observed. In the DNA extracted from P. putida $\mathrm{IBB}_{\mathrm{Po} 19}$, the detected fragment has higher size (approximately $220-230 \mathrm{bp}$ in length), as compared with the fragment of the $\operatorname{rhl} \mathrm{AB}$ gene detected in $P$. aeruginosa $\mathrm{IBB}_{\mathrm{P} \text { 20 } 0}$ and $\mathrm{IBB}_{\mathrm{Po} 22}$ (216 bp); no significant changes in the PCR pattern were observed in the DNA extracted from $P$. putida $\mathrm{IBB}_{\mathrm{Po19}}$. The PCR of rhlAB gene confirmed the production of anionic rhamnolipid surfactants by $P$. aeruginosa $\mathrm{IBB}_{\mathrm{Po} 20}$ and $\mathrm{IBB}_{\mathrm{Po} 22}$. Due to their characteristics (e.g., high affinity for hydrophobic molecules, high emulsifying 
a.

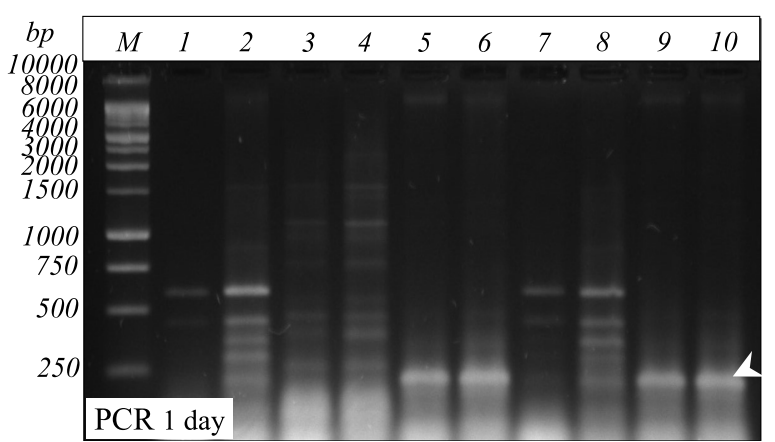

b.

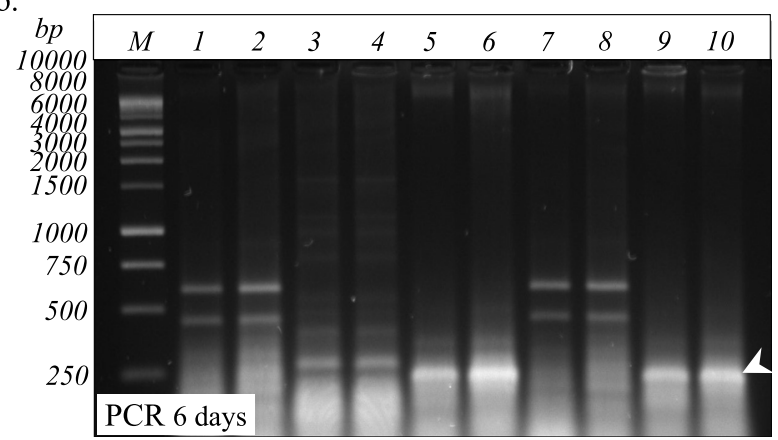

Fig. 5 Detection of $r$ hIAB gene in DNA extracted from Achromobacter and Pseudomonas strains. a PCR using DNA extracted after 1 day

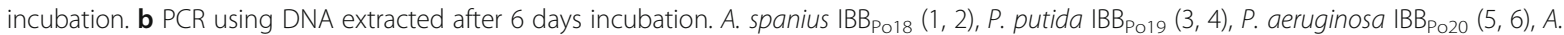
spanius IBBpo21 $(7,8)$, P. aeruginosa IBBpo22 $(9,10)$, control $(1,3,5,7,9)$, kerosene $(2,4,6,8,10)$; PCR of rh/AB gene (216 bp fragment) using rhIA-f/ rhlB-r primers (1-10); 1 kb DNA ladder, Promega (M)

activity, low critical micelle concentration values), surfactants and especially glycolipid biosurfactants, such as rhamnolipids, were reported to improve the biodegradation of many petroleum and petroleum products (Rocha et al. 2011; Chrzanowski et al. 2012).

\section{Pigments}

The ability of the isolated bacteria to produce extracellular pigments, such as pyocyanin and pyoverdin pigments, was confirmed by determining the formation of blue-green colonies on King A and yellow-green fluorescent colonies

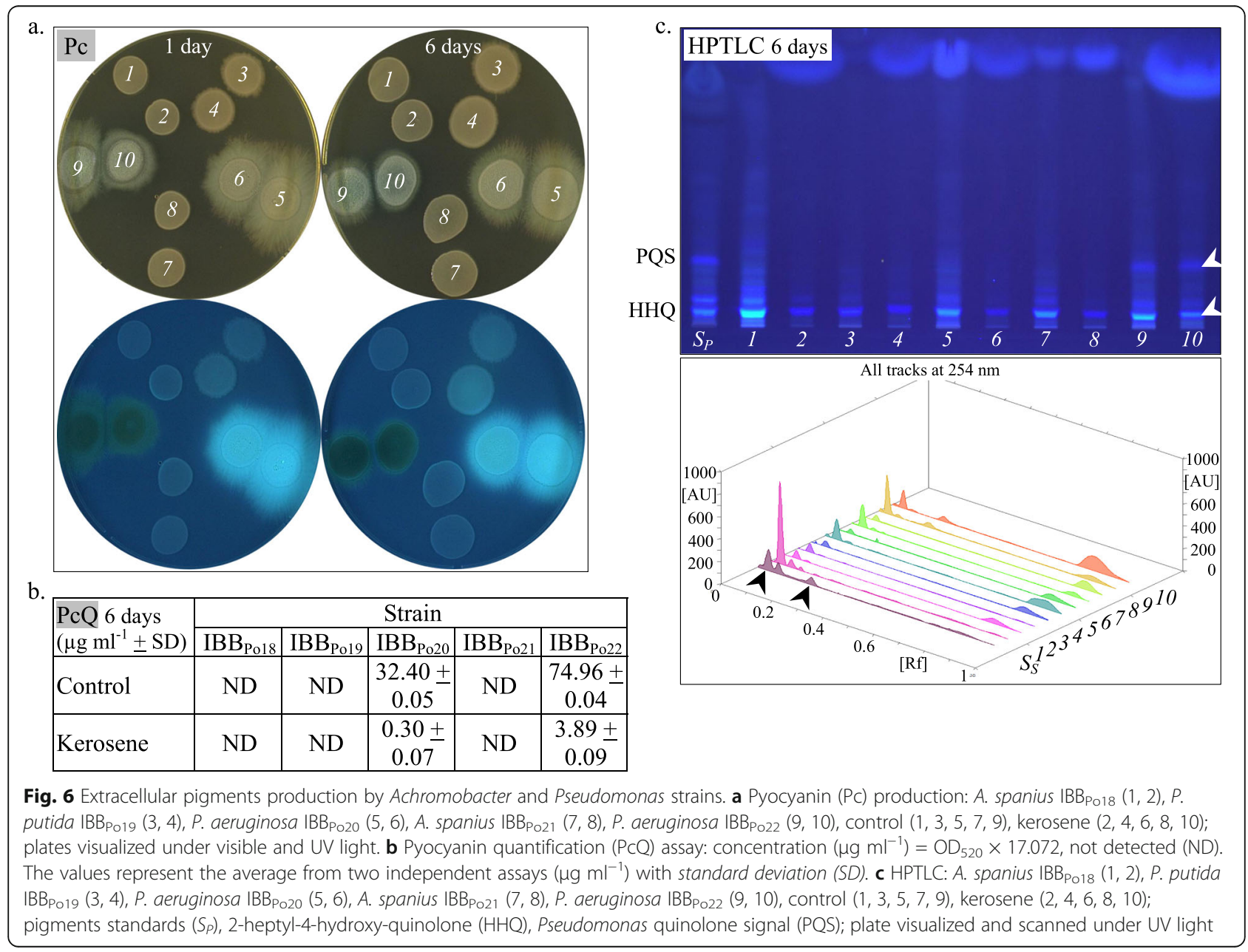


on King B agar, respectively. Although all tested bacteria were able to grow on these agar media, the pyocyanin (Fig. 6a) and/or pyoverdin pigments production was observed only for $P$. aeruginosa isolates. $P$. aeruginosa $\mathrm{IBB}_{\mathrm{Po} 20}$ produced both pyocyanin and pyoverdin pigments, while $P$. aeruginosa $\mathrm{IBB}_{\mathrm{Po} 22}$ produced only pyocyanin. The ability of these two $P$. aeruginosa strains to produce pigments varies from one bacterium to another, and even for the same bacterium depending on the culture conditions. The pyocyanin pigments extracted from $P$. aeruginosa $\mathrm{IBB}_{\mathrm{Po} 20}$ and $\mathrm{IBB}_{\mathrm{Po22}}$ showed characteristic peaks at 205-210, 275, 390, and $525 \mathrm{~nm}$, and the pigment production significantly decreased from 32.40 to $0.30 \mu \mathrm{g}$ $\mathrm{ml}^{-1}$ and from 74.96 to $3.89 \mu \mathrm{g} \mathrm{ml}^{-1}$, respectively, when these bacteria were grown in the presence of kerosene (Fig. 6b). Furthermore, significant differences between UV-Vis absorption spectra of the pyocyanin pigments extracted from the bacterial cells grown in the presence of kerosene were observed, as compared with their coresponding controls (data not shown). In the acidic form, pyocyanin pigments extracted from other Pseudomonas strains (i.e., $P$. aeruginosa $\mathrm{R}_{1} P$. aeruginosa $\mathrm{U}_{3}$ ) showed characteristic peaks at 300, 388, and $518 \mathrm{~nm}$ (El-Fouly et al. 2015). Hydroxy-alkyl-quinoline (HAQ) metabolite production by tested bacteria was monitored by HPTLC analyses of the crude pigment extracts. When the TLC plate was visualized under UV light (Fig. 6c), several fractions with $R_{\mathrm{f}}$ values of $0.04-0.50$ were observed in extracts from A. spanius $\mathrm{IBB}_{\mathrm{Po} 18}$ and $\mathrm{IBB}_{\mathrm{Po} 21}$, P. putida $\mathrm{IBB}_{\mathrm{Po} 19}$, and $P$. aeruginosa $\mathrm{IBB}_{\mathrm{Po} 20}$ and $\mathrm{IBB}_{\mathrm{Po} 22}$, and the number of these fractions varies from one bacterium to another. The spot with $R_{\mathrm{f}}$ values of $0.04-0.06$ and $0.18-0.21$ correspond probably to HAQs metabolites, such as 2-heptyl-4-hydroxy-quinolone (HHQ) and 2-heptyl-3-hydroxy-4quinolone or Pseudomonas quinolone signal (PQS), respectively. All our bacteria were able to produce $\mathrm{HHQ}$, while the production of $\mathrm{PQS}$ was observed only in $P$. aeruginosa $\mathrm{IBB}_{\mathrm{Po} 20}$ and $\mathrm{IBB}_{\mathrm{Po} 22}$. According with literature, $\mathrm{PQS}$ and its precursor HHQ are secondary metabolites produced by various bacteria, including by Pseudomonas sp. strains which act as signaling molecules in cell-to-cell communication in the quorum
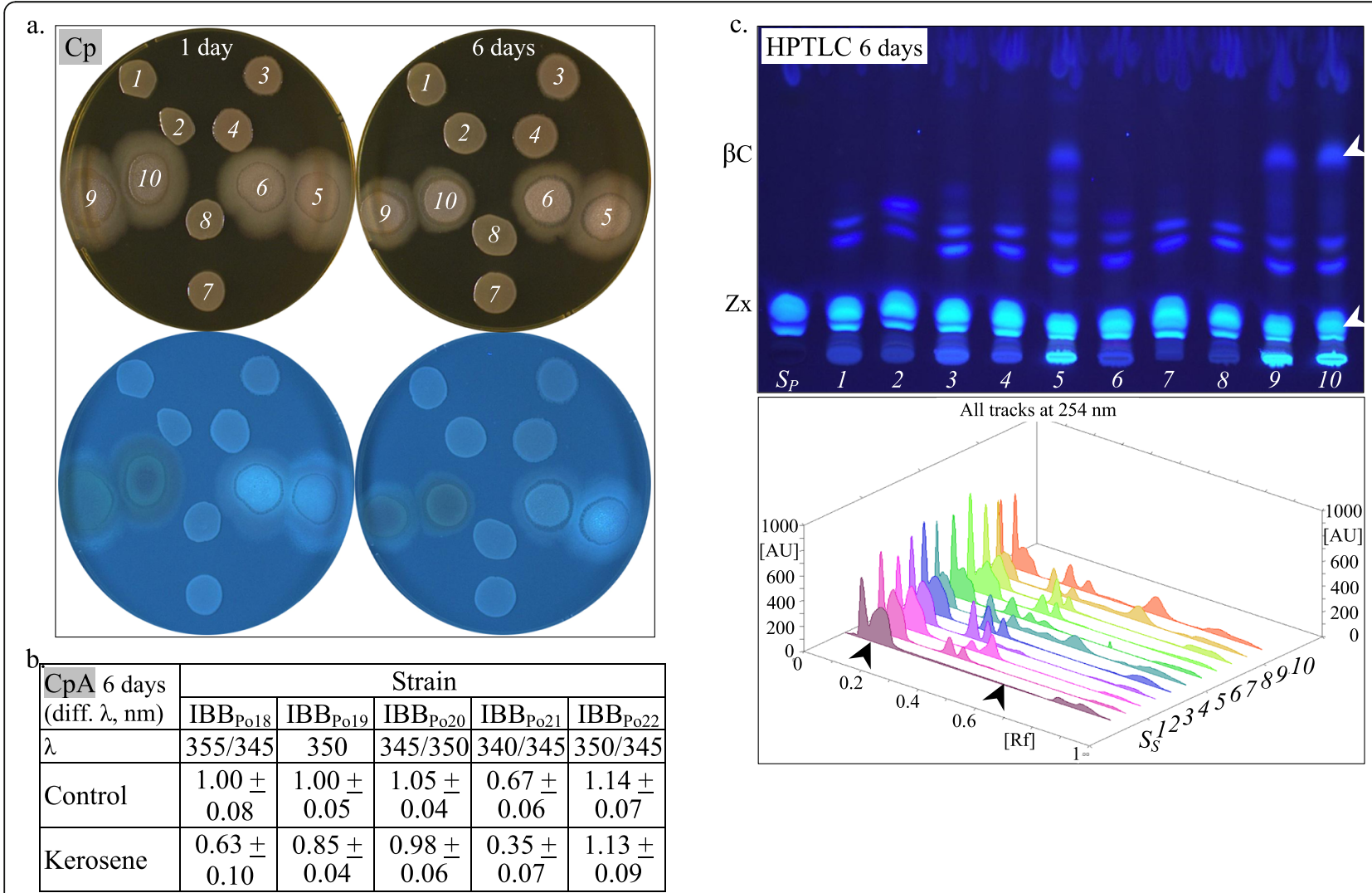

Fig. 7 Intracellular pigments production by Achromobacter and Pseudomonas strains. a Carotenoid pigment (Cp) production: A. spanius IBBpo18 (1,

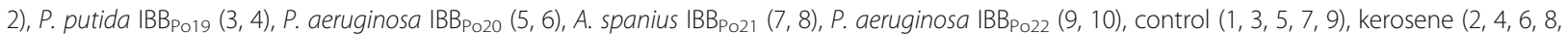
10); plates visualized under visible and UV light. b Carotenoid pigments absorption (CpA) maxima at different wavelengths ( $\lambda$ ). The values represent the average from two independent assays (nm) with standard deviation (SD). c HPTLC: A. spanius IBBpo18 (1, 2), P. putida IBBpo19 (3, 4), P. aeruginosa $\operatorname{IBB} B_{020}(5,6)$, A. spanius $\operatorname{IBB}_{\text {po21 }}(7,8)$, P. aeruginosa $\operatorname{IBB}_{\mathrm{po} 22}(9,10)$, control $(1,3,5,7,9)$, kerosene $(2,4,6,8,10)$; pigments standards $\left(S_{p}\right)$, zeaxanthin (Zx or $\beta, \beta$-carotene-3,3'-diol), $\beta$-carotene ( $\beta C)$; plate visualized and scanned under UV light 
sensing system (Jensen et al. 2006; Niewerth et al. 2011). PQS signaling is directly or indirectly involved in regulation of secondary metabolite production (e.g., pigments, surfactants) and virulence factor production, biofilm formation, motility, and also in membrane vesicle formation. HHQ and PQS exhibit also a very good antimicrobial activity against various Grampositive and Gram-negative bacteria (Jensen et al. 2006; Niewerth et al. 2011; Reen et al. 2011). The isolation of new bacteria able to produce HAQs metabolites is very important and will make possible the discovery of new therapeutic strategies to combat microorganisms which are refractory to conventional antimicrobial agents (Reen et al. 2011).

The ability of the isolated bacteria to produce intracellular pigments, such as carotenoids, was also investigated. Creamy pigments which showed absorption maxima between 340 and $355 \mathrm{~nm}$ were produced by $A$. spanius $\mathrm{IBB}_{\mathrm{Po} 18}$ and $\mathrm{IBB}_{\mathrm{Po} 21}$, P. putida $\mathrm{IBB}_{\mathrm{Po} 19}$, and $P$. aeruginosa $\mathrm{IBB}_{\mathrm{Po} 20}$ and $\mathrm{IBB}_{\mathrm{Po} 22}$ (Fig. 7a, b). According with literature (Sajilata et al. 2008), cis-zeaxanthin isomers show absorption in the near-UV region (320-340 $\mathrm{nm})$, while trans-isomers absorb in the visible region $(400-500 \mathrm{~nm})$. Significant differences between UV-Vis absorption spectra of the carotenoid pigments extracted from the bacterial cells grown in the presence of kerosene were observed, as compared with their coresponding controls (data not shown). Production of carotenoids by Achromobacter and Pseudomonas isolates was monitored also by HPTLC analyses of the crude pigment extracts. When the TLC plate was visualized under UV light (Fig. 7c), several fractions with $R_{\mathrm{f}}$ values of $0.06-$ 0.58 were observed in extracts from A. spanius $\mathrm{IBB}_{\mathrm{Po18}}$ and $\mathrm{IBB}_{\mathrm{Po} 21}, P$. putida $\mathrm{IBB}_{\mathrm{Po19}}$, and $P$. aeruginosa $\mathrm{IBB}_{\mathrm{Po} 20}$ and $\mathrm{IBB}_{\mathrm{Po22}}$, and the number of these fractions varies from one bacterium to another. The spots with $R_{\mathrm{f}}$ values of $0.10-0.16$ which correspond probably to zeaxanthin ( $\mathrm{Zx}$ or $\beta, \beta$-carotene-3,3'-diol) were detected in all the isolated bacteria extracts, while the spots with $R_{\mathrm{f}}$ values of $0.57-0.58$ which correspond to $\beta$-carotene $(\beta C)$ were detected only in $P$. aeruginosa extracts.

Pigments produced by different bacteria have been extensively used in food and textile industries, paper production, agricultural practices, water science, and technology (Malik et al. 2012; Usman et al. 2017). Furthermore, the pigments (e.g., pyocyanin, carotenoids) which showed useful biological activities, such as antioxidants, antibiotic, and anticancer agents, have also been used in medicine (Malik et al. 2012; El-Fouly et al. 2015; Usman et al. 2017).

\section{Conclusions}

Five Proteobacteria from Beta- and Gamma- classes were isolated from different samples polluted with petroleum and petroleum products. Based on their morphological, biochemical, and molecular characteristics, isolated bacteria were identified as $A$. spanius strains $\mathrm{IBB}_{\mathrm{Po} 18}$ and $\mathrm{IBB}_{\mathrm{Po} 21}, P$. putida strain $\mathrm{IBB}_{\mathrm{Po19}}$, and $P$. aeruginosa strains $\mathrm{IBB}_{\mathrm{Po} 20}$ and $\mathrm{IBB}_{\mathrm{Po} 22}$. All the isolated bacteria were able to tolerate and degrade kerosene, and their tolerance and degradation rates vary from one bacterium to another. Achromobacter and Pseudomonas isolates were able to produce several secondary metabolites (i.e., surfactants, pigments), and their production varies from one bacterium to another. Glycolipid surfactants produced by Achromobacter and Pseudomonas isolates have a very good emulsification activity, and their activity increased in the presence of kerosene. Pyocyanin and pyoverdin pigments were produced only by $P$. aeruginosa $\mathrm{IBB}_{\mathrm{Po} 20}$ and $\mathrm{IBB}_{\mathrm{Po} 22}$, while carotenoid pigments were produced by all the isolated bacteria. Significant changes in pigment production were observed when Achromobacter and Pseudomonas isolates were grown in the presence of kerosene. Due to their ability to tolerate and degrade kerosene, and also to produce secondary metabolites, the bacteria which were isolated in this study could be used in the bioremediation of environments polluted with complex mixtures of hydrocarbons, such as kerosene.

\section{Acknowledgements}

The author is grateful to Ana Dinu for technical support.

Authors' contributions

The author read and approved the final manuscript.

\section{Funding}

The study was funded by project no. RO1567-IBB05/2019 from the Institute of Biology Bucharest of Romanian Academy.

Ethics approval and consent to participate

This article does not contain any studies with human participants or laboratory animals.

Consent for publication

Not applicable.

Competing interests

The author declares that there are no competing interests.

Received: 30 September 2019 Accepted: 8 January 2020

\section{References}

Abdel-Mawgoud AM, Aboulwafa MM, Hassouna NAH (2009) Characterization of rhamnolipid produced by Pseudomonas aeruginosa isolate Bs20. Appl Biochem Biotechnol 157:329-345

Ahamed F, Hasibullah M, Ferdouse J, Anwar MN (2010) Microbial degradation of petroleum hydrocarbon. Bangladesh J Microbiol 27:10-13

Altschul SF, Madden TL, Schäffer AA, Zhang J, Zhang Z, Miller W, Lipman DJ (1997) Gapped BLAST and PSI-BLAST: a new generation of protein database search programs. Nucl Acids Res 25:3389-3402

Beuttler H, Hoffmann J, Jeske M, Hauer B, Schmid RD, Altenbuchner J, Urlacher VB (2011) Biosynthesis of zeaxanthin in recombinant Pseudomonas putida. Appl Microbiol Biotechnol 89:1137-1147

Chikere CB, Okpokwasili GC, Chikere BO (2011) Monitoring of microbial hydrocarbon remediation in the soil. 3. Biotech 1:117-138

Chrzanowski Ł, Ławniczak Ł, Czaczyk K (2012) Why do microorganisms produce rhamnolipids? World J Microbiol Biotechnol 28:401-419 
Eberlin LS, Abdelnur PV, Passero A, de Sa GF, Daroda RJ, de Souza V, Eberlin MN (2009) Analysis of biodiesel and biodiesel-petrodiesel blends by high performance thin layer chromatography combined with easy ambient sonicspray ionization mass spectrometry. Analyst 134:1652-1657

El-Fouly MZ, Sharaf AM, Shahin AAM, El-Bialy Heba A, Omara AMA (2015) Biosynthesis of pyocyanin pigment by Pseudomonas aeruginosa. J Rad Res Appl Sci 8:36-48

Gesheva V, Stackebrandt E, Vasileva-Tonkova E (2010) Biosurfactant production by halotolerant Rhodococcus fascians from Casey Station, Wilkes Land, Antarctica. Curr Microbiol 61:112-117

Gulati D, Mehta S (2017) Isolation and identification of petrol degrading microorganisms from contaminated soil and comparison of their bioremediation potential. Int Res J Pharm 8:34-38

Holt JG, Krieg NR, Sneath PHA, Staley JT, Williams ST (1994) Bergey's Manual of Determinative Bacteriology, 9th edn. Williams and Wilkins, Baltimore

Jensen V, Löns D, Zaoui C, Bredenbruch F, Meissner A, Dieterich G, Münch R, Häussler S (2006) RhlR expression in Pseudomonas aeruginosa is modulated by the Pseudomonas quinolone signal via PhoB-dependent and -independent pathways. J Bacteriol 188:8601-8606

Joy S, Rahman PKSM, Sharma S (2017) Biosurfactant production and concomitant hydrocarbon degradation potentials of bacteria isolated from extreme and hydrocarbon contaminated environments. Chem Eng J 317:232-241

King EO, Ward MK, Raney DE (1954) Two simple media for the demonstration of pyocyanin and fluorescin. J Lab Clin Med 44:301-307

Leahy JG, Colwell RR (1990) Microbial degradation of hydrocarbons in the environment. Microbiol Rev 54:305-315

Malik K, Tokkas J, Goyal S (2012) Microbial pigments: a review. Int J Microbial Resource Technol 1:361-365

Marchesi JR, Sato T, Weightman AJ, Martin TA, Fry JC, Hiom SJ, Wade WG (1998) Design and evaluation of useful bacterium-specific PCR primers that amplify genes coding for bacterial 165 rRNA. Appl Environ Microbiol 64:795-799

Matilla MA (2018) Problems of solventogenicity, solvent tolerance: an introduction. In: Krell T (ed) Cellular Ecophysiology of Microbe: Hydrocarbon and Lipid Interactions, Handbook of Hydrocarbon and Lipid Microbiology. Springer, Cham, pp 327-334

Mazumdar A, Deka M, Hazarika DJ (2015) Degradation of kerosene hydrocarbon by indigenous diazotrophic bacteria isolated from crude oil contaminated soil. Int J Bioassays 4:4184-4188

Medina G, Juárez K, Valderrama B, Soberón-Chávez G (2003) Mechanism of Pseudomonas aeruginosa RhIR transcriptional regulation of the rhIAB promoter. J Bacteriol 185:5976-5983

Michaud L, Di Cello F, Brilli M, Fani R, Lo Giudice A, Bruni V (2004) Biodiversity of cultivable Antarctic psychrotrophic marine bacteria isolated from Terra Nova Bay (Ross Sea). FEMS Microbiol Lett 230:63-71

Mnif S, Chamkha M, Labat M, Sayadi S (2011) Simultaneous hydrocarbon biodegradation and biosurfactant production by oilfield-selected bacteria. J Appl Microbiol 111:525-536

Niewerth H, Bergander K, Chhabra SR, Williams P, Fetzner S (2011) Synthesis and biotransformation of 2-alkyl-4(1H)-quinolones by recombinant Pseudomonas putida KT2440. Appl Microbiol Biotechnol 91:1399-1408

Pacwa-Płociniczak M, Anna PG, Poliwoda A, Piotrowska-Seget Z (2014) Characterization of hydrocarbon-degrading and biosurfactant-producing Pseudomonas sp. P-1 strain as a potential tool for bioremediation of petroleum-contaminated soil. Environ Sci Pollut Res 21:9385-9395

Patowary K, Patowary R, Kalita MC, Deka S (2016) Development of an efficient bacterial consortium for the potential remediation of hydrocarbons from contaminated sites. Front Microbiol 7:1092 https://doi.org/10.3389/fmicb.2016.01092

Pini F, Grossi C, Nereo S, Michaud L, Lo Giudice A, Bruni V, Baldi F, Fani R (2007) Molecular and physiological characterisation of psychrotrophic hydrocarbon-degrading bacteria isolated from Terra Nova Bay (Antarctica). Eur J Soil Biol 43:368-379

Provvedi R, Kocíncová D, Doná V, Euphrasie D, Daffé M, Etienne G, Manganelli R, Reyrat JM (2008) SigF controls carotenoid pigment production and affects transformation efficiency and hydrogen peroxide sensitivity in Mycobacterium smegmatis. J Bacteriol 190:7859-7863

Reen FJ, Mooij MJ, Holcombe LJ, McSweeney CM, McGlacken GP, Morrissey JP, O'Gara F (2011) The Pseudomonas quinolone signal (PQS), and its precursor $H H Q$, modulate interspecies and interkingdom behaviour. FEMS Microbiol Ecol 77:413-428

Rikalović MG, Vrvić MM, Karadžić IM (2015) Rhamnolipid biosurfactant from Pseudomonas aeruginosa - from discovery to application in contemporary technology. J Serb Chem Soc 80:279-304
Ritchie G, Still K, Rossi J, Bekkedal M, Bobb A, Arfsten D (2003) Biological and health effects of exposure to kerosene-based jet fuels and performance additives. J Toxicol Environ Health B Crit Rev 6:357-451

Rocha CA, Pedregosa AM, Laborda F (2011) Biosurfactant-mediated biodegradation of straight and methyl-branched alkanes by Pseudomonas aeruginosa ATCC 55925. AMB Express 1:9 https://doi.org/10.1186/2191-0855-1-9

Sajilata MG, Singhal RS, Kamat MY (2008) The carotenoid pigment zeaxanthin - a review. Comp Rev Food Sci Food Saf 7:29-49

Sambrook J, Russel D (2001) Molecular Cloning: A Laboratory Manual, 3rd edn. Cold Spring Harbor Laboratory Press, Cold Spring Harbor, New York

Sardessai YN, Bhosle S (2004) Industrial potential of organic solvent tolerant bacteria. Biotechnol Prog 20:655-660

Satpute SK, Bhawsar BD, Dhakephalkar PK, Chopade BA (2008) Assessment of different screening methods for selecting biosurfactant producing marine bacteria. Indian J Marine Sci 37:243-250

Shahzadi S, Khan Z, Rehman A, Nisar MA, Hussain SZ, Asma ST (2019) Isolation and characterization of Bacillus amyloliquefaciens 6A: a novel kerosene oil degrading bacterium. Environ Technol Innov 14:100359 https://doi.org/10. 1016/j.eti.2019.100359

Siegmund I, Wagner F (1991) New method for detecting rhamnolipids excreted by Pseudomonas species during growth on mineral agar. Biotechnol Techn 5: 265-268

Silva RMP, Rodriguez AA, de Oca JMGM, Moreno DC (2006) Biodegradation of crude oil by Pseudomonas aeruginosa AT18 strain. Tecnol Quimica 26:70-77

Silva SNRL, Farias CBB, Rufino RD, Luna JM, Sarubbo LA (2010) Glycerol as substrate for the production of biosurfactant by Pseudomonas aeruginosa UCP0992. Coll Surf B Biointerfaces 79:174-183

Stancu MM (2018) Production of some extracellular metabolites by a solventtolerant Pseudomonas aeruginosa strain. Waste Biomass Valori 9:1747-1755

Stancu MM, Grifoll M (2011) Multidrug resistance in hydrocarbon-tolerant Grampositive and Gram-negative bacteria. J Gen Appl Microbiol 57:1-18

Usman HM, Abdulkadir N, Gani M, Maiturare HM (2017) Bacterial pigments and its significance. MOJ Bioequiv Availab 4:285-288

Varjani SJ (2017) Microbial degradation of petroleum hydrocarbons. Biores Technol 223:277-286

Xu X, Liu W, Tian S, Wang W, Qi Q, Jiang P, Gao X, Li F, Li H, Yu H (2018) Petroleum hydrocarbon-degrading bacteria for the remediation of oil pollution under aerobic conditions: a perspective analysis. Front Microbiol 9: 2885 https://doi.org/10.3389/fmicb.2018.02885

\section{Publisher's Note}

Springer Nature remains neutral with regard to jurisdictional claims in published maps and institutional affiliations.

Ready to submit your research? Choose BMC and benefit from:

- fast, convenient online submission

- thorough peer review by experienced researchers in your field

- rapid publication on acceptance

- support for research data, including large and complex data types

- gold Open Access which fosters wider collaboration and increased citations

- maximum visibility for your research: over $100 \mathrm{M}$ website views per year

At $\mathrm{BMC}$, research is always in progress.

Learn more biomedcentral.com/submissions 